\title{
The Road to Good Governance: Via the Path Less Accountable? The Effectiveness of Fiscal Accountability in Liberia
}

\author{
$\underline{\text { Abstract }}$ \\ Accountability mechanisms are touted as a path to 'good governance.' But are accountability \\ mechanisms a sure route to achieving the objectives of 'good governance'? Limited case studies \\ have offered inconsistent evidence (Devas \& Grant 2003; Charlick 2001; Blair 2000). But \\ empirical evidence of the relationships between principles of good governance- - high citizen \\ participation, low levels of corruption, high-quality service delivery — and accountability \\ mechanisms is lacking. We examine the effectiveness of accountability mechanisms in Liberia \\ and find relationships between measures of county-level fiscal accountability and measures of \\ good governance do not always produce expected results, making fiscal accountability \\ mechanisms no guarantee for achieving goals of good governance.
}

\section{Introduction}

There is currently great emphasis in the developing world, and particularly in Africa, on applying the tenets of 'good governance' as a means for achieving sustainable development. In fact, good governance is often defined by these tenets. The World Bank defines 'good governance’ as that which is “participatory, transparent and accountable...effective and equitable... and...promotes the rule of law” (UNDP 1997). According to the World Bank, good governance requires sound public sector management, accountability, exchange and free flow of information, and a legal framework for development (www.worldbank.org).

This emphasis on good governance is due in part to the benefits it is expected to produce in developing countries: poverty reduction, human development progress, and improvements to 
infrastructure and services. In particular, strong voice and accountability mechanisms and reductions in corruption are thought to contribute to sustained and equitable growth (Kaufmann 2010). This assumption is reflected in the six core dimensions of good governance measured by the Worldwide Governance Indicator Project (WGI), which include: voice and accountability, political stability \& absence of violence, effectiveness of government, regulatory ability/quality, rule of law, and control of corruption (www.govindicators.org).

One way to advance the practice of good governance is through a process known as democratic local governance (DLG). DLG is a "process of decentralization whereby real responsibility and authority are transferred to local bodies that are accessible and accountable to local citizens who enjoy full political rights and liberties” (Blair 2000; p. 21). DLG encompasses two central ideas: participation gives citizens a meaningful voice in local government decisions, while accountability allows people to hold local government responsible (Blair 2000). Both of these ideas are core components of good governance, but with an emphasis at the local level. The purported benefits of DLG also echo those of good governance: better policy decisions that benefit all constituents, improved service delivery, and reductions in poverty. A focus on strengthening and promoting institutional structures for good governance, such as accountability mechanisms, may help accomplish these two central objectives of DLG, thereby closing the gap between needs of citizens and capabilities of state institutions (Gaventa 2002).

Deeply interwoven within these concepts of good governance and democratic local governance (DLG) are the repeated themes of accountability, citizen participation, lack of corruption, and service delivery (Boncodin 2007; Smoke 2003; Blair 2000; Crook \& Manor 1995). Again and again, accountability mechanisms are touted as a path to 'good governance' governance that encompasses broad participation of its constituents, is responsive to the needs of 
its citizens, maintains low levels of corruption, and sustains adequate levels of service delivery and performance.

But are accountability mechanisms a sure route to good governance? And can they effectively contribute to goals such as increased political participation, decreased corruption, and improved service delivery, especially at the local level? On these questions, the jury is still out. Existing evidence tends to case studies, and is often contradictory. For example, Blair's USAID case studies on the impact of democratic local governance (DLG) initiatives in six developing countries (Bolivia, Honduras, India, Mali, the Philippines, and the Ukraine) concluded that DLG has "encouraged participation, and...increased representation, but...provided little in the way of empowerment, and even less in making the distribution of benefits more equitable or reducing poverty” (Blair, 2000, p. 25).

The empirical relationships between the principles that comprise good governance and DLG- including strong citizen participation, lack of corruption, and high-quality service delivery- are complex and it is often difficult to determine direction of causality. We begin to address this gap by examining the effectiveness of fiscal accountability mechanisms in Liberia at the county level. The relationship between measures of fiscal accountability at the county level, and citizens' local political participation, perceptions of corruption, and perceptions of service delivery will be explored. This study contributes to multiple literatures, including fiscal accountability, subnational corruption, and local political participation.

The following literature review first discusses accountability in a broad context, as well as explores mechanisms of fiscal accountability. Next, accountability is discussed relative to three main tents of good governance - government that encompasses broad citizen participation, maintains low levels of corruption, and sustains adequate levels of service delivery. Data and 
methods are reviewed in detail, and findings and implications from quantitative analysis are shared. Finally, steps for future research are proposed.

\section{Theoretical Discussion}

Broadly defined, accountability involves the duty of public officials to report and inform on governmental activities, with a corresponding right of the public to impose sanctions on their behavior and outcomes. (Ackerman 2005; Koehane 2002). Fiscal accountability requires that both citizens and central government have accurate and publicly accessible information about government: information about available resources, service levels and performance, budgets, accounts and other financial indicators (Devas \& Grant 2003). It also requires the institutionalization of methods of examination by those who have the required skills, such as auditors and inspectors; so that citizens can have confidence in the information they receive. A large body of research relies on use of legal and financial institutions such as the judiciary and financial auditors, or outside structures such as the media and civil society, to strengthen and enforce accountability in the public sector (see Devas \& Grant 2003; Svensson 2005). In many poor countries, however; these institutions are weak and corrupt themselves. Nor are there adequate mechanisms for holding elected officials accountable for outcomes in terms of the actual use of resources and delivery of services. Lack of transparency in budgetary procedures and outcomes makes it hard for the electorate to judge government spending records (Healey and Tordoff, 1995; Goetz and Gaventa, 2001).

So how can fiscal accountability mechanisms be strengthened? One route to stronger accountability is via citizen enforcement through increased public access to information. When citizens are more informed about government performance, they can pressure public officials to perform duties in the public interest (Shah \& Schacter 2005). Public officials are held 
accountable due to increased transparency. In fact, there is data that suggests improving citizen access to public information and giving citizens more right to action can reduce corruption (Svensson 2005; Reinikka \& Svensson 2004b). Other scholarship contests this assertion, claiming that accountability is not automatically improved through increased access to citizen information. Citizens are unable to hold remote political institutions accountable for their own personal experiences as they do not have the cognitive abilities nor the detailed aggregate information to do so (Khemani 2007).

One way to increase citizen access to information is through fiscal accountability mechanisms such as citizen access to financial records, explanation of regulations, and the ability of citizens to participate more directly in the budget process. This sort of fiscal oversight may reduce corruption because local government resources can be more easily scrutinized and controlled by citizens through access to information. If integrated into a larger public management system, such systems may help tackle corruption. There is another side to these ideas, however. Other scholars argue accountability mechanisms designed to increase citizen access to information may in fact create more bureaucratic problems and red tape, and actually decrease citizen confidence and participation in government, while increasing opportunity for and incidence of corruption (Apaza 2012). This type of accountability and oversight is particularly important in Liberia because after fourteen years of civil war that finally ended in 2003, "central to postwar reconstruction efforts...has been economic reform that address the failure of public institutions to stem corruption” (Chessen \& Krech 2006, p. 4). Yet these authors point out evidence illustrates continued failures in the realm of economic governance in Liberia. 


\section{Accountability \& Political Participation}

Democratic local governance (DLG) posits that by bringing the government closer to the people, more will participate. Offering citizens more opportunities to participate and influence resource allocation will result in local policy decisions that better reflect the needs of all groups, thereby increasing equity and decreasing poverty (Smoke 2003; Blair 2000). There is therefore a great deal of interest in increasing political participation and making government more responsive to the needs of all constituents, particularly underrepresented ones. One route to reaching these objectives may be through use of strong mechanisms of accountability. For example, fiscal accountability mechanisms such as scorecards, report cards, and budget audits may improve transparency and increase access to information. Increasing citizen involvement in the local policy-making process via citizen councils and participatory budgeting may enhance the direct participation of citizens in the political process. These accountability mechanisms allow citizen scrutiny through access to information, as well as equip citizens with true decisionmaking authority.

Brian Wampler’s work in Latin America illustrates these ideas. Wampler surveyed delegates in eight Brazilian municipalities that utilized a Participatory Budgeting (PB) program to determine which factors influence participants' attitudes and behaviors towards local political participation (2007). Wampler asked citizen delegates if they believe they have decision-making authority and if they have modified their strategies for securing public goods through the use of participatory budgeting mechanisms. He found that municipalities where PB was used successfully combined increased citizen knowledge with real citizen decision-making authority that allowed individuals to influence public policy decisions and to monitor the outcomes in 
order to change how government acts. His findings support the idea that institutions can alter citizen attitudes and behaviors relative to local political participation (Wampler 2007).

This example from Brazil supports the argument that improved institutional design via mechanisms of accountability can encourage political participation. But others warn that participation of the poor and marginalized is not straightforward, and barriers exist for entry into participatory institutions. Institutional improvements in situations of state incapacity and ineffectiveness, pervasive corruption, and individual resource constraints may or may not result in citizens entering into the participatory sphere (Denhardt et al 2009; Cornwall \& Coelho 2007). This contradiction leads us to ask questions about the effects of fiscal accountability mechanisms on local political participation in Liberia:

Research Question 1: Do stronger county-level fiscal accountability mechanisms result in higher citizen participation at the local level in Liberia?

\section{Corruption and Accountability}

Corruption can be defined as "the misuse of public office for private gain” (Sandholtz \& Koetzle 2000, 32; Beekman et al 2011). Corruption involves real costs: worldwide, bribery has been estimated to cost $\$ 1$ trillion per year, or 3\% of global income (Rose-Ackerman 2004). A higher level of perceived corruption thwarts national development, hinders the goals of good governance, and results in serious political, economic, and social costs (Boucher et al 2007; Ayittey 2000; Kaufmann 1999; Mauro 1995; Berki \& Perry 1998). Cross-nationally, one of the strongest and most consistent findings is that lower perceived corruption correlates closely with higher economic development (see LaPorta et al 1999; Ades \& DiTella 1999; Treisman 2000). Due to the severe negative impacts associated with corruption, central governments, aid agencies 
and civil society organizations in developing countries have increased their focus on anticorruption strategies, and the priorities of anti-corruption efforts often include attempts to strengthen institutions of accountability (www.worldbank.org/anticorruption; Huther \& Shah 2000).

Some scholars suggest that corruption may actually be higher at the local level due to closer and more frequent interactions between citizens and officials at these more decentralized levels (Prud'homme 1995; Tanzi 1995). Local government is a locus of resource allocation that supports provision of basic governmental services, so the subnational level often gives greater discretion to public officials with less oversight (Transparency International Working Paper \#5 2009). But what if accountability mechanisms are in place at the local level to provide needed oversight and transparency? Can these accountability mechanisms be effective in combating corruption?

Institutions of vertical accountability between citizens and government institutions may in fact reduce opportunities for corruption (Diamond and Morlino 2005). Accountability mechanisms have the potential to reduce corruption because citizens who are better informed about government performance can mobilize for sanctions, such as voting corrupt officials out of office. At the local level, increased accountability should reduce corruption through improved access to information that results in increased local ownership (Bardhan and Mookherjee 2000). But another line of reasoning claims even if increased transparency leads to actual reductions in acts of corruption, the perceptions of corruption by citizens may increase as they become more aware of local government's successes and failures. They may perceive local government institutions as more corrupt than they had before (Crook \& Manor 2000). 
Institutional reform that strengthens accountability and increases transparency may reduce corruption, real or perceived, but as yet these are hypothesized relationships and not based on empirical evidence (Konold 2007). This paper empirically tests such relationships by asking if Liberian citizens who live in counties with more mechanisms of fiscal accountability perceive less corruption:

Research Question 2: Do stronger county-level fiscal accountability mechanisms result in lower perceived corruption by Liberian citizens?

\section{Accountability and Service Delivery}

Democratic local governance (DLG) is a method of empowering local governments through increased resources and responsibilities, but also through mechanisms of accountability that ensure local governments are held responsible for delivery of public services. There is agreement among scholars that the degree of local government accountability to citizens has an impact on delivery of public services (Eckardt 2007; Deininger \& Mpuga 2005). In Uganda, Deininger \& Mpuga (2005) find accountability mechanisms have a strong impact on service quality as measured by both user satisfaction and changes in service quality over time. Households with knowledge of how to report inappropriate behavior by bureaucrats and communicate dissatisfaction with service delivery (thereby creating a channel for accountability via information, reporting and sanction) were associated with improvements in citizen perceptions of service delivery (p. 275). While perceptions of citizen satisfaction with service delivery may not always correlate with external measures of administrative performance data, customer satisfaction is still an important part of accountability (Kelly \& Swindell 2002).

Mechanisms that increase accountability should reduce opportunistic behavior of elected officials and improve public service provision (Eckardt 2007). Therefore, we would expect higher degrees of accountability to be associated with higher levels of public service provision, 
and poor service delivery to be linked with weak accountability mechanisms. We test this hypothesis through a bivariate analysis of the relationship between fiscal accountability mechanisms and citizen perceptions of service delivery in Liberia:

Research Question 3: Is there a statistically significant relationship between county-level fiscal accountability mechanisms in Liberia and citizen perceptions of local service performance?

\section{Data and Methods}

So far, systematic and empirical evidence that speaks to the effectiveness of fiscal accountability mechanisms is lacking, as are explanations of why accountability mechanisms work or do not work. The challenge then is to both evaluate and enhance the effectiveness of these mechanisms (Apaza 2011; Rose-Ackerman 1989). This paper attempts to do just that using county-level fiscal accountability data illustrated through the Liberian context.

This study aims to empirically test the following relationships: 1) between Liberian county-level fiscal accountability mechanisms and local citizen participation, and 2) between Liberian county-level fiscal accountability mechanisms and citizen perceptions of corruption, and 3) to begin to explore the relationship between Liberian county-level fiscal accountability mechanisms and citizen perceptions of local service delivery. To test these relationships, we need to connect citizen attitudes about government and information about local political participation with information about fiscal accountability at the subnational level. To do this, we combine a measure of subnational fiscal corruption obtained using CENTAL’s 2007 Liberia Local Government Toolkit with individual-level survey data from Round 4 of the Afrobarometer survey in Liberia. 
The Center for Transparency and Accountability in Liberia (CENTAL) is a nongovernmental, anti-corruption organization founded in May of 2004. CENTAL promotes "positive change and a vision for a transparent and integrity-based society" in Liberia (www.cental.org). CENTAL worked with Global Integrity to develop improved measurement of and increased access to fiscal accountability information via the Liberia Local Governance Toolkit. The Liberia Local Governance Toolkit is an accountability tool for understanding the strengths, weaknesses and overall effectiveness of Liberia's governance, accountability, and anticorruption mechanisms at the county level. The 2007 Liberia Local Government Toolkit provides a subnational "integrity scorecard” for each of Liberia's 15 counties. This scorecard can be used as an objective measure of county- level accountability in five major categories. We utilize county-level scorecard data in the "budget transparency" category, which comprises a measure of fiscal accountability.

The results of the 2007 subnational integrity scorecard showed great scoring variation across counties in the budget transparency sub-category, which assesses accountability mechanisms for budget transparency and oversight, the effectiveness of these mechanisms, and citizen access to these mechanisms. Some counties, such as Grand Bassa and Lofa, earned moderate scores, while others, such as Grand Cape Mount and River Gee, earned very weak scores. While the Liberian national government is required to publicly disclose the transfer of funds to sub-national governments in almost all counties, public access to the regulations and receipts of such funds, as well as access to the budgetary process more broadly, varies tremendously. The fiscal accountability measures available in the Liberia Local Governance Toolkit can be used to examine the relationship between Liberian subnational fiscal 
accountability, participation in the local political system, perceptions of corruption, and citizen satisfaction with service delivery.

These county-level fiscal accountability scores will be attached to individual-level data contained in the 2008 Round 4 Afrobarometer survey in Liberia. Each of Liberia's 15 counties is represented in the data. The Afrobarometer survey is a nationally-representative, random, stratified sample of 1,200 Liberians who participated in face-to-face interviews in December of 2008 (www.afrobarometer.org). In addition to basic demographic information, the Afrobarometer collects data about individual attitudes and behavior, including questions about democracy, governance, livelihoods, macro-economics and markets, social capital, conflict and crime, citizen participation, and national identity. To create the data set used for our quantitative analysis, the county-level budget transparency construct available from CENTAL's Local Governance Toolkit that measures fiscal accountability was attached to individual Afrobarometer survey responses. This is possible because each survey response indicates which county the respondent is from. We use this new data set to create three separate models, two of which use OLS regression for analysis, and a third model in which bivariate analysis offers preliminary exploration.

\section{Variables and Measures}

\section{Dependent Variables}

We analyze three dependent variables in three separate models_Local Political Participation, Perceptions of Local Corruption, and Quality of Local Service Delivery. A full list 
of the survey items that make up each of these three indexed measures ${ }^{1}$ can be found in Appendix A.

Model 1 uses Local Political Participation as the dependent variable, which is an indexed measure of how engaged Liberians are in political activities in their local communities. This indexed variable was compiled from a set of six self-reporting responses that asked respondents about how often (on a four-point scale from "never"=0 to "many times"=3) they had engaged in certain political activities in the local community, including discussing problems with others, joining with others to address local problems, writing or calling local media, and making complaints to local government either in person or in writing. The index variable had a potential range of participation from 0-18 for each respondent-indicating how many local political acts each respondent reported they participated in. The basic frequency distribution is shown in Graph 1.

\section{[Graph 1 About Here]}

We did not include voting as a local political act in our index for two reasons. First, as a newly consolidating democracy having only just completed its second national democratic elections in 2011, voter turnout is Liberian is exceptionally high in all counties and may skew results. Second, Liberians vote in national elections for the president and members of the national legislature. There is currently no opportunity to vote for local officials. Lastly, since previous scholarship views voting as a blunt instrument, and political participation involves much more than just voting in elections, we focus on other forms of political participation that

\footnotetext{
${ }^{1}$ Although the rule of thumb for treating a categorical variable as continuous is that the variable must contain at least 8 or more categories, due to limitations of available data we have treated the three indexed dependent variables in each of the three models as continuous even though they contain fewer than 8 categories. All other variables in the model are either binary, continuous, or they have been statistically tested to see if they can be treated as intervallevel variables. In cases where categorical independent variables did not meet requirements for treatment as intervallevel variables, dummy variables for each possible response category were created and one less than the number of dummies was used in the regression equation.
} 
hold elected officials accountable not just through elections. In fact, some scholars believe political activities other than voting may be more important (Bratton et al 2005). Therefore, our focus for this research is on local-level political participatory acts other than voting, as indicated by the measures comprising our local political participation index.

The dependent variable in Model 2, Perceptions of Local Corruption, asked Liberians to evaluate the extent to which they believed a series of government officials are corrupt. Respondents were asked to rate the president, national legislature, local government officials, national government officials, police, tax officials, judges, and traditional leaders. This measure asked respondents to identify on a four-point scale ranging from 0 to 3 whether "none," "some of them," "most of them," or "all of them" in each of these categories of officials were involved in corruption. These eight responses were combined to create an index of perceived corruption with a potential range from 0-24 for each respondent. The frequency distribution for this measure is shown in Graph 2.

\section{[Graph 2 About Here]}

Model 3 uses Quality of Service Delivery as an indexed dependent variable that incorporates six measures of local government service quality. Respondents were asked to rate "how well or badly" the local government provided certain local public services (quality of road maintenance, local market maintenance, health standards in restaurants and food stalls, fee collections, and tax collection) on a 4-point scale from "very badly" to "very well." These six measures were combined to create an overall index of local service quality with a potential range from 0-24. The frequency distribution for this measure is shown in Graph 3.

[Graph 3 About Here] 


\section{Independent Variables}

Our two theoretical independent variables include an individual-level measurement of citizen perceptions of local accountability and an aggregate county-level measure of accountability. Local government accountability is measured using an Afrobarometer survey question that asked respondents how well local government officials were following accountability procedures such as making local government’s program of work known, providing citizens information about the local budget, allowing citizens to participate in local government decisions, consulting others before making decisions, effectively handling complaints, and guaranteeing proper use of public funds. These six items were measured on a 4point scale from “very badly” to "very well” and were combined into an indexed summary variable ranging from 0-24 (local accountability index).

We also used an objective measure of accountability by augmenting the Afrobarometer dataset with the county-level measure developed by CENTAL. This item evaluated each county’s integrity in sub-national fiscal accountability processes by assessing the level of transparency in the budget processes on a scale of 0 (very weak) to 100 (very strong) and using the mean of these evaluations to create a single assessment for each country. The evaluative criteria for each county-level assessment is included in Appendix B. We converted these numerical rankings to a 6-point scale ranging from low to high levels of transparency. This county-level accountability measure was added to each individual respondent's case in the Afrobarometer dataset based on the county they resided in to create a county level transparency independent variable.

In Models 1 and 2, our independent variables also include well-established demographic and SES controls. We control for such standard demographics as gender, age, and education—all 
of which have been found to have a relationship to political participation (see Bratton et al 2005; Verba et al 1995; Verba \& Nie 1972). Because rural life in Liberia is apt to offer fewer chances to participate politically as well as less exposure to the political process and governmentprovided services, we incorporate a dummy variable for whether a respondent lives in a rural or urban area. A dummy variable for whether a respondent indicated a party attachment (1=yes; 0=no) was also included in both the Local Political Participation and Perceptions of Corruption models as well.

To these controls we also add several variables that are traditionally used to explain political participation (see Bratton et al 2005; Verba et al 1995; Verba \& Nie 1972). These include voluntary group membership, which asked the respondent to describe their level of engagement in community or social groups other than religious organizations ${ }^{2}$. We also include two measures of political efficacy, political efficacy and local political efficacy. The political efficacy measure is a proxy for overall internal political efficacy that asks about an individual's ability to influence political representatives. This measure is based on the survey question that asked respondents how likely it was that they could make their "representative to the National Legislature listen to [their] concerns about a matter of importance to the community?” Local political efficacy asks the same question about local officials. Both questions measure responses on the same 4-point scale from "not at all likely” to "very likely.”

Model 1, Local Political Participation, also incorporates a variable measuring the extent to which respondents indicated they had been exposed to political corruption in the course of their interaction with different governmental institutions. This indexed variable, experience with corruption, combines three items that asked how frequently the respondent had to offer bribes or

\footnotetext{
${ }^{2}$ The Afrobarometer survey separates group membership into "religious" and "other voluntary and community group memberships." Religious group membership was not found to have any statistical significance in any of the models.
} 
gifts and/or pay off a government official to complete routine government business such as obtaining a permit.

Model 2, Perceptions of Corruption, includes the same demographic, party attachment, and political efficacy variables ${ }^{3}$. We also include several independent variables that have been previously documented as influencing the perception of the openness of political systemsperceptions of the cleanliness of the country's elections and the respondents satisfaction with democracy ${ }^{4}$. Both models 1 and 2 employ OLS regression.

Model 3, Quality of Service Delivery, is exploratory in nature. Little research has been done to determine what affects how individuals in new democracies perceive the quality of the services governments provide, let alone how accountability or perceived corruption may affect those perceptions. In addition, it is not just individual-level variables that will affect perceptions of service delivery. There are likely community-level characteristics that also influence these perceptions, such as amount of local fiscal transfers and expenditures. Here, we provide a simple bivariate analysis demonstrating only the relationship between the local accountability index and these perceptions, which can be used as the basis for building a full model that includes both individual- and community-level variables in the future.

\section{Findings}

Regression results for Model 1, Local Political Participation, are displayed in Table 1.

We find that Liberian local political participation is enhanced by membership in community groups and strength of party attachment, which supports the findings of Bratton et al (2005).

Both political efficacy and local political efficacy have a positive relationship with local political

\footnotetext{
${ }^{3}$ In model 2, both the political efficacy and local political efficacy variables did not meet the standard requirements for inclusion in the regression analysis as interval-level variables. Thus, they are included as separate dummy variables for each response.

${ }^{4}$ Both the electoral cleanliness and satisfaction with democracy did not meet the standard requirements for inclusion in the regression analysis as interval-level variables in this model. Thus, they are included as separate dummy variables for each response.
} 
participation. Having personal experience with corruption in government also serves to encourage political participation. Alternatively, living in an urban area of the country and being a woman depress political participation. Interestingly, traditionally powerful predictors of participation- age and education- seem to bear no effect in the Liberian context. Some of our findings support those of existing research on African political participation, while others are in disagreement. For example, when assessing voting determinants in a cross-national study in 10 countries in Africa, Kuenzi and Lambright (2010) found strength of party attachment and associational membership to be associated with an increase in the propensity to vote. In contrast to our findings, however, Keunzi and Lambright found that age and education also influenced voter turnout. When predicting political participation, specifically non-voting behaviors including contacting and communing, Bratton et al (2005) find generation and gender to have an influence. Our findings support this as well. We find, however, that living in a rural area suppresses political participation, while Bratton et el (2005) find this has a positive relationship to participation.

\section{[Table 1 About Here]}

Key to our analysis here are the effects of our two accountability measures. We find that both the actual existence of stronger mechanisms of accountability—as evidenced by CENTAL's rankings in our county-level transparency measure—and higher perceptions by Liberians of effective local accountability mechanisms (local accountability index) slightly discourage political participation.

Model 2 reveals how political conditions affect Liberians’ perceptions of corruption in government. While demographics have little impact beyond a marginally significant increase in 
perception of corruption from respondents in urban areas of the country, the political variables and local conditions do.

We find that individuals with lower levels of political efficacy ("not at all likely") are less likely to perceive corruption, while other levels of efficacy have no statistically significant effect. Being aligned with a political party (party attachment) has a similar, though weaker, effect. Not surprisingly, respondents who reported being very satisfied with democracy were also less likely to perceive government officials as being corrupt. The analysis indicates that the higher the citizens’ perceived quality of local service delivery, the less likely Liberians are to perceive corruption. This variable, in fact, had the largest coefficient in the model.

Other variables were associated with an increase in the perception of corruption.

Respondents with high levels of local political efficacy (“a great deal”) perceived higher level of corruption.While the coefficients declined with the level of efficacy, no other levels of local efficacy demonstrated a statistically significant effect.

The condition of the political system's effect was clear. Perceptions of corruption were higher for respondents who were "not at all" satisfied with democracy as well as for those who viewed elections as either "not free and fair" or "free and fair with major problems."

Finally, in Model 2 only one of the two theoretical variables was statistically significant. The county-level transparency independent variable demonstrated in counties with higher levels of objective levels of accountability, there are actually higher levels of perceived corruption by citizens. The local accountability index, an index of citizens' perceptions of accountability, did not reach statistical significance.

[Table 2 about here] 
In Model 3, we simply look at the relationship between citizens’ perceptions of local accountability and perceptions of the quality of local service delivery. This limited analysis indicates that more favorable views of local accountability are associated with weaker perceptions of local service quality.

[Table 3 about here]

\section{Implications and Conclusions}

The quest for 'good governance' and 'democratic local governance' emphasizes the importance of concepts such as broad political participation, low levels of corruption, and adequate service delivery. Subnational accountability mechanisms are intended to play a role in reaching these objectives. Despite the importance of the local environment, little empirical research has been conducted at the subnational level that examines the relationship between accountability mechanisms and citizen's participation in the local political system, perceptions of corruption, and perceptions of quality of local service delivery. This study represents an effort to build the theoretical basis for this vein of research, as well as to empirically examine the effectiveness of subnational fiscal accountability mechanisms and contribute to clarifying relationships between accountability, political participation, corruption, and service delivery at the local level. Liberia provides an excellent context for this research due to its emphasis on good governance, fiscal transparency, and accountability during this period of democratic consolidation and post-war reconstruction.

Further research is needed to replicate results, however; our findings suggest that while mechanisms for fiscal accountability are in fact significantly correlated to local political participation and perceived corruption, stronger accountability mechanisms do not automatically result in more participation and decreased corruption. In fact, our results indicate that increased 
fiscal accountability may lead to citizen apathy and slightly lower political participation, perhaps because increased access to information about how local government is managing resources and providing services means citizens do not feel the need to mobilize for change or complaint. As more citizens move from rural areas of Liberia to the urban capital of Monrovia, this may also be affecting participation, as we find that those who live in urban environments are less likely to engage in participatory acts. Our findings also support the theory that increased accountability can actually increase perceived corruption, as increased transparency may bring to light previously unknown misdeeds and opportunistic actions by public officials.

There are practical implications for this research in the quest for good governance and democratic local governance (DLG). Accountability matters- but how much? And why? How does it relate to broader good governance efforts that seek to attain increased accountability, broader political participation, anti-corruption efforts, and improvements to service delivery? The answers to these questions will ensure time, energy, and resources devoted to the pursuit of good governance and DLG are more fruitful. Central and local governments, aid agencies, and NGOs that are devoting resources towards achieving the goals associated with good governance and DLG want to know these resources are being used effectively and achieving desired outcomes. They also need to understand how the different aspects of good governance interrelate and how they might affect each other. Increasing our knowledge about these relationships will only further efforts towards reaching the goals of good governance and DLG.

There are limitations to our research. This study relies on static data from one survey and does not take into account changes that may occur over time. Future research should attempt to replicate results using additional Afrobarometer and Liberia Local Governance Toolkit data from future rounds. Another area for future research is to examine variations in the models by each of 
the 15 counties in Liberia. This study also does not consider a full model for the possible relationship between local fiscal accountability and service delivery performance. Building a complete model that includes individual- and community-level variables, as well as citizen perceptions and administrative performance benchmarks, should be a goal for future research. Finally, there may be additional factors at play that influence the relationship between accountability, participation, corruption and service delivery, and the nature and direction of these relationships has not been fully explored in our models.

Despite these limitations, this study makes contributions to the literature on fiscal accountability and democratic local governance, taking important initial steps to advance the theoretical basis of this literature, and initiating an empirical examination of the complex relationships between accountability, political participation, perceived corruption, and local service delivery performance. This research can lead to practical insights on the effectiveness of fiscal accountability as a mechanism to achieve good governance. 


\section{Appendix A. Survey Questions Combined in Dependent Variable Indices.}

\section{Local Political Participation Index}

Includes items asking the respondent how often they participated in the following activities:

1. Discuss the problem with other people in your community?

2. Join with others in your community to address the problem?

3. Discuss the problems with other community, religious, or traditional leaders?

4. Write a letter to a newspaper or call a radio show?

5. Make a complaint to local government officials, for example, by going in person or by writing a letter?

6. Make a complaint to other government officials, for example, by going in person or by writing a letter?

\section{Perceptions of Corruption}

How many of the following people do you think are involved in corruption, or haven't you heard enough about them to say?

1. President and her officials

2. Representatives of National Legislature

3. Local Government Officials

4. National Government Officials

5. Police

6. Tax Officials

7. Judges and Magistrates

8. Traditional Leaders

\section{Quality of Service Delivery Index}

How well would you say your local government is handling the following matters:

1. Maintaining local roads

2. Maintaining local market places

3. Maintaining health standards in public restaurants and food stalls

4. Keeping our community clean (e.g., refuse removed)

5. Collecting license fees on bicycles, carts and barrows

6. Collecting rates on privately owned houses 


\section{Appendix B. Survey Items for Theoretical Variables}

Local Accountability Index

Includes items asking the respondent how well they thought their local government performed the following activities:

1. Making the local government's program of work known to ordinary people

2. Providing citizens with information about the local government's budget (i.e. revenues and expenditures)

3. Allowing citizens like yourself to participate in local government decisions

4. Consulting others (including traditional, civic and community leaders) before making decisions

5. Providing effective ways to handle complaints about local government officials

6. Guaranteeing that local government revenues are used for public services and not for private gain

Country-Level Transparency

Evaluated each county based on 0-100 summary of considerations in each of the following three (3) categories:

Can citizens access the sub-national budgetary process?

Are there transparent regulations governing the transfer of funds from national to sub-national governments?

Are the regulations governing the transfer of funds from national to sub-national governments effective? 


\section{References}

J. M. Ackerman, “Human Rights and Social Accountability.” Social Development Papers: Participation and Civic Engagement. Paper No.86. May 2005.

Ades, A. \& R. DiTella. “Rents, Competition and Corruption.” American Economic Review. 1999.

Apaza, C. "Ensuring Accountability and Transparency Through Integrated Public Management Systems.” Political Science \& Politics. 45(2): 435-441. 2012.

Apaza, C. Integrity and Accountability in Government, Homeland Security and the Inspector General. Farnham: Ashgate.

Ayittey, G. B. N. “Combating Corruption in Africa: Analysis \& Context.” Macmillan Press Ltd. 2000.

P. Bardhan \& D. Mookherjee. “Capture and Governance at Local and National Levels.” The American Economic Review. Papers and Proceedings of the One Hundred Twelfth Annual Meeting of the American Economic Association. 90 (2): 135-139. 2000.

Beekman, G., E. Bulte \& E. Nillsen. "Corruption, Investments \& Contributions to Public Goods: Experimental Evidence From Rural Liberia.” Working Paper: Development Economics Group. 2011.

Blair, H. "Participation and Accountability at the Periphery: Democratic Local Governance in Sex Countries.” World Development. 28(1): 21-29. 2000.

Boncodin, E.T. “Citizen Engagement in Budgeting \& Public Accountability.” $6{ }^{\text {th }}$ Session, Committee of Experts in Public Administration. April 10-14, 2007. United Nations, NY, NY.

Boucher, A., W. Durch, M. Midyette, S. Rose, \& J. Terry. "Mapping and Fighting Corruption in War Torn States.” Report from the Project on Rule of Law in Post-Conflict Settings. Stimson Center Report No. 61. Future of Peace Operations Program. March 2007.

Bratton, M., R. Mattes \& E. Gyimah-Boadi. Public Opinion, Democracy, and Market Reform in Africa. Cambridge University Press. 2005.

Burki. S. \& G. Perry. Beyond Washington Consensus: Institutions Matter. Washington D.C. World Bank. 1998.

Charlick, R.B. “Popular Participation and Local Government Reform.” Public Administration and Development. 21: 149-157. 2001.

Chessen, M. \& R. Krech. "Post-War Reconstruction in Liberia: The Government and Economic Management Assistance Program (GEMAP).” Unpublished paper. 2006. 
Cornwell, A. \& V. S. P. Coelho. "Spaces for Change? The Politics of Participation in New Democratic Arenas. Zed Books. 2007.

Cornwell, A. \& J. Gaventa. "Bridging the Gap: Citizenship, Participation, and Accountability." PLA Notes 40. International Institute for Environment and Development. February 2001.

Crook, R. \& J. Manor. "Democratic Decentralisation and Institutional Performances: Four Asian and African Experiences Compared.” Journal of Commonwealth and Comparative Politics. 33(3): 309-334. 1995.

Deininger, K. \& P. Mpuga. “Does Greater Accountability Improve the Quality of Public Service Delivery?” World Development. 33(1):171-191. 2004.

Denhardt, J., \& L. Terry, E. R. Delacruz, L. Andonoska. "Barriers to Citizen Engagement in Developing Countries.” International Journal of Public Administration. 32: 1268-1288. 2009.

Devas, N. \& Grant, U. “Local Government Decision-Making- Citizen Participation and Local Accountability: Some Evidence From Kenya and Uganda.” Public Administration and Development. 23: 307-316. 2003.

Diamond, L. \& L. Morlino, eds. Assessing the Quality of Democracy. Journal of Democracy Series. Johns Hopkins University Press. 2005.

Eckardt, S. "Political Accountability, Fiscal Conditions, and Local Government Performance: Cross-Sectional Evidence from Indonesia. Institute of Local Public Finance. Working Paper \#022007. 2007.

Gaventa, J. “Exploring Citizenship, Participation, and Accountability.” IDS Bulletin. 2002.

Gaventa. J. \& Valderrama, C. “Participation, Citizenship, and Local Governance.” Background note prepared for workshop entitled Strengthening Participation in Local Governance. Institute of Development Studies. June 21-24, 1999.

Goetz, A.M. \& J. Gaventa. "Bringing Citizen Voice and Client Focus into Service Delivery. IDS Working Paper 138. Brighton. 2001.

Gurger, T. \& A. Shah. “Localization and Corruption: Panacea or Pandora’s Box?” World Bank Policy Research Working Paper 3486. January 2005.

Healey, J. and Tordoff, W., eds. Votes and Budgets: Comparative Studies in Accountability in the South. Basingstoke. Macmillan. 1995.

Huther, J. \& A. Shas. “A Simple Measure of Good Governance.” Public Services Delivery. Edited by A. Shah. The World Bank. 2005.

Kaufmann, D. “On Africa’s New Damn: From Premature Exuberance to Tempered Optimism.” Brooking Institution. 2011. 
Kaufmann, D. “Governance Matters 2010: Worldwide Governance Indicators Highlight Governance Successes, Reversals, and Failures. Brookings Institution. 2010.

Kaufmann, D., A. Kraay \& P. Ziodo-Lobaton. “Governamce Matters.” World Bank Policy Research Working Paper No. 2196. World Bank. Washington D.C. 1999.

Kelly, J. \& D. Swindell. “A Multiple-Indicator Approach to Municipal Service Evaluation: Correlating Performance Measurement and Citizen Satisfaction Across Jurisdictions.” Public Administration Review. 62(5): 610-621.

Keohane, R. O. “Global Governance and Democratic Accountability.” Miliband Lectures. London School of Economics. Spring 2. 2002.

Khemani, Stuti. "Can Information Campaigns Overcome Political Obstacles to Serving the Poor?” The Politics of Service Delivery in Democracies. Better Access for the Poor. Ed. Shantayanan Devarajan and Ingrid Widlund. 2007.

Konold, C. "Perceived Corruption, Public Opinion, and Social Influence in Senegal.” Afrobarometer Working Paper No. 85. December 2007.

LaPorta, R., F. Lopez-de-Silanes, A. Shleifer, \& R. Vishny. “The Quality of Government.” Journal of Law, Economics \& Organization. 15 (1): 222-279. 1999.

Lederman, D., N. Loayza, \& R. Soares. “Accountability and Corruption: Public Institutions Matter.” Economics \& Politics. 17 (1). March 2005.

Mauro, P. “Corruption and Growth.” Quarterly Journal of Economics. 110 (3): 681-712. 1995.

Prud'homme, R. On The Dangers of Decentralization. World Bank Research Observer 10(2): 201-210. 1995.

Reinikka, R. \& J. Svensson. “Local Capture: Evidence From a Central Government Transfer Program in Uganda.” Quarterly Journal of Economics. 119(2): 679-705. 2004a.

Rose-Ackerman, S. Which Bureaucracies are Less Corruptible? Political Corruption, ed. Heidenheimer \& LeVine. 803-26. New Jersey. Transaction. 1989.

Rose-Ackerman, S. Corruption and Government: Causes, Consequences, and Reform. Cambridge University press. Cambridge. UK. 1999.

Rose-Ackerman, S. Corruption and Government: Causes, Consequences, and Reform. New York. Cambridge University Press. 2004.

Sandholtz, W. \& W. Koetzle. “Accounting for Corruption: Economic Structure, Democracy, and Trade.” International Studies Quarterly. 44: 31-50. 2000. 
Shah, A. \& M. Schacter. "Combating Corruption: Look Before you Leap.” World Bank Publications. 2005.

Smoke, R. "Decentralisation in Africa: Goals, Dimensions, Myths \& Challenges.” Public Administration \& Development. 23: 7-16. 2003.

Svensson, J. “Eight Questions About Corruption.” Journal of Economic Perspectives. 19 (3): 1942. Summer 2005.

Tanzi, V. Corruption Around the World: Causes, Consequences, Scope, and Cures. IMF Staff Papers. 45 (4): 559-594. 1998.

Treisman, D. “The Causes of Corruption: A Cross-National Study.” Journal of Public Economics. 76: 399-457. 2000.

Treisman, D. "What Have we Learned About the Causes of Corruption From Ten Years of Cross-National Empirical Research?” Annual Review of Political Science. 10: 211-244. 2007.

Verba, S. and N. Nie. Participation in America: Political Democracy and Social Equality. 1972.

Verba, S., \& N. Nie, et al. Participation and Political Eqaulity: A Seven-Nation Comparison. 1978.

Wampler, B. (2007). "Can Participatory Institutions Promote Pluralism? Mobilizing LowIncome Citizens in Brazil." Studies in Comparative International Development 41(4): 57-78.

“Corruption and Local Government.” Transparency International Working Paper \#5. 2009.

\section{Data Sets:}

Afrobarometer. 20 Country Survey. Michigan State University. African Studies Center. Liberia: 2008.

Liberia Local Governance Toolkit. Global Integrity and CENTAL. 2007. 
Graph 1: Frequency Distribution of Dependent Variable in Model 1: Local Political Participation

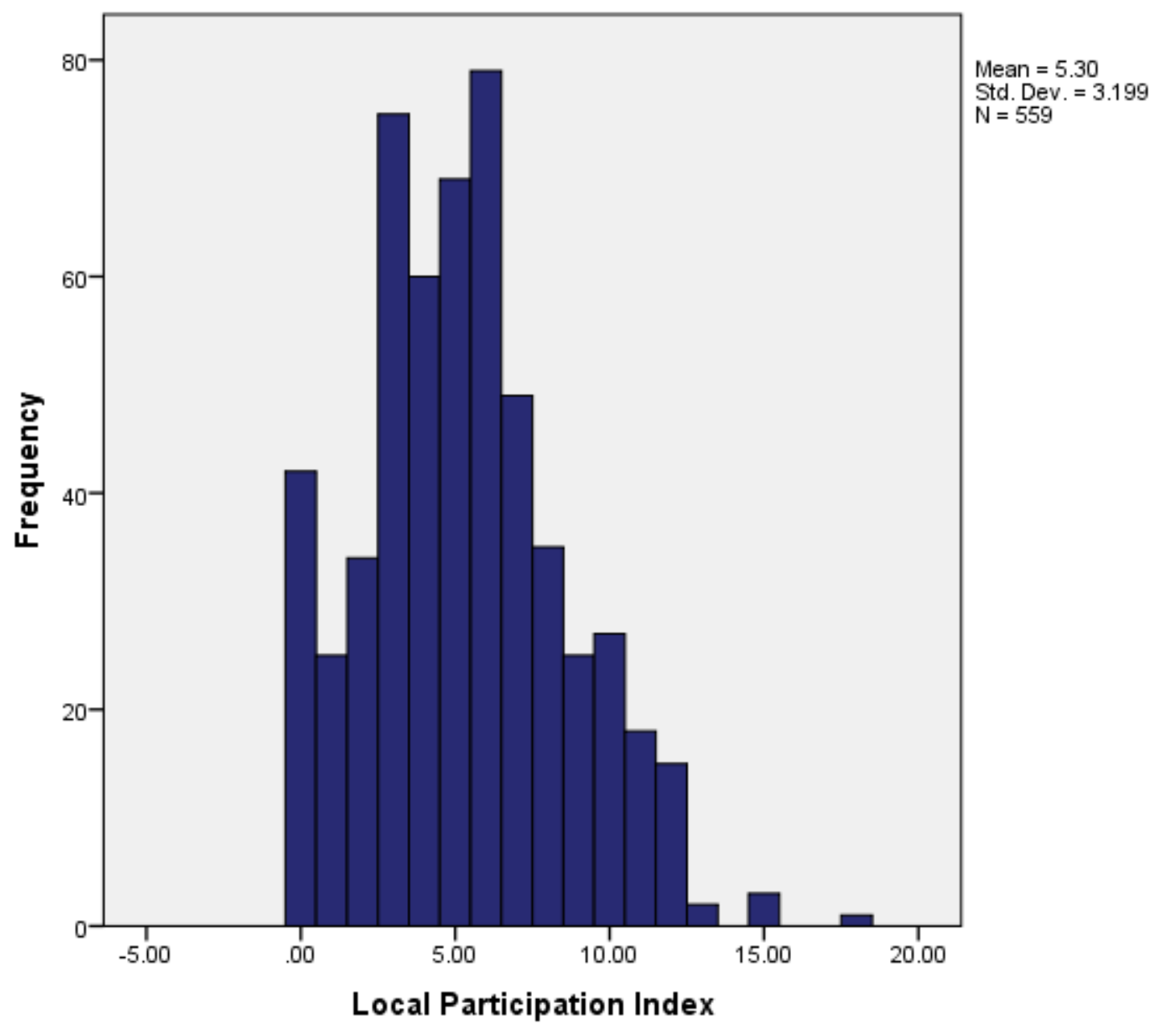


Graph 2: Frequency Distribution of Dependent Variable in Model 2: Perceptions of Local Corruption

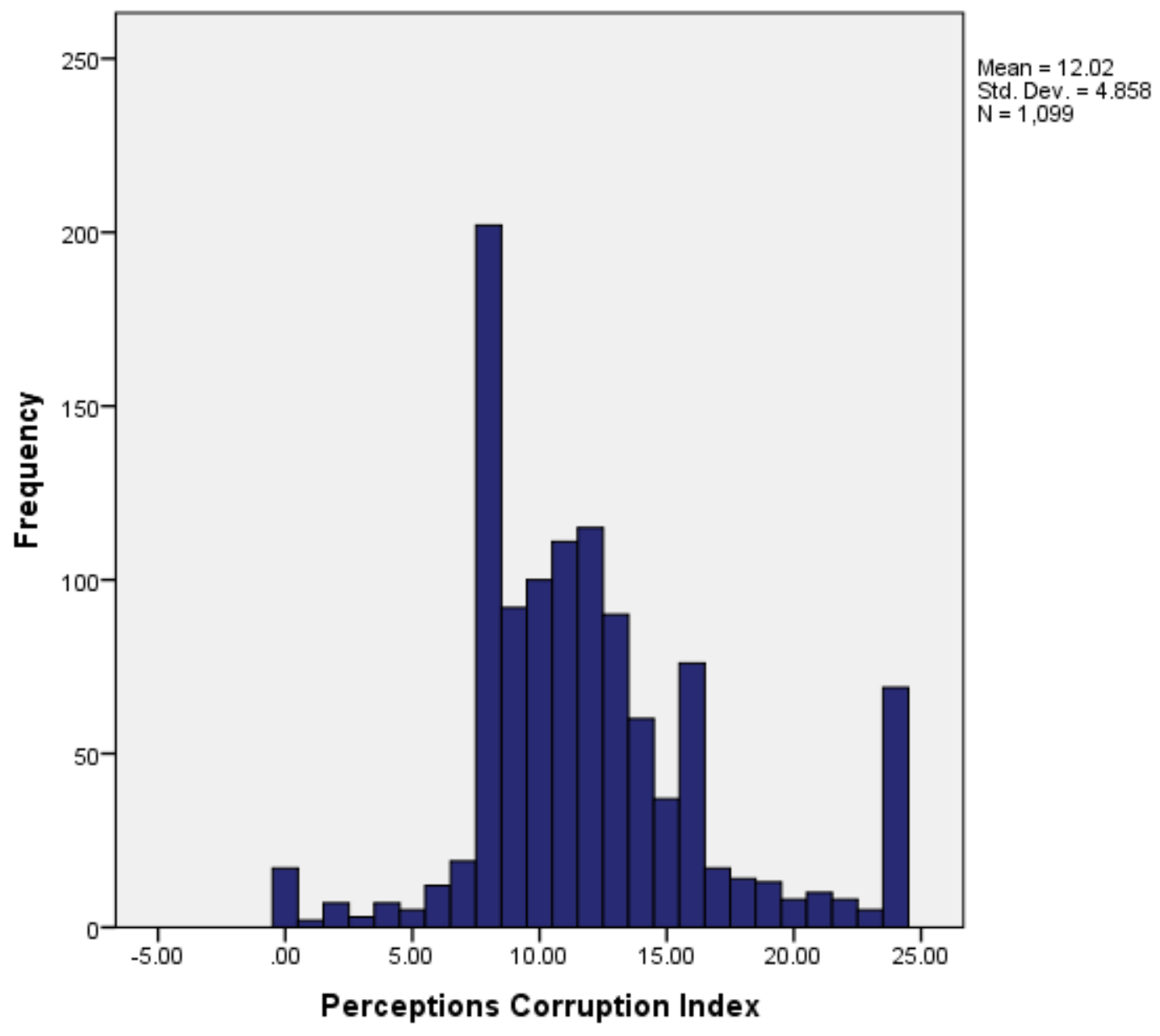


Graph 3: Frequency Distribution of Dependent Variable in Model 3:

Quality of Service Delivery

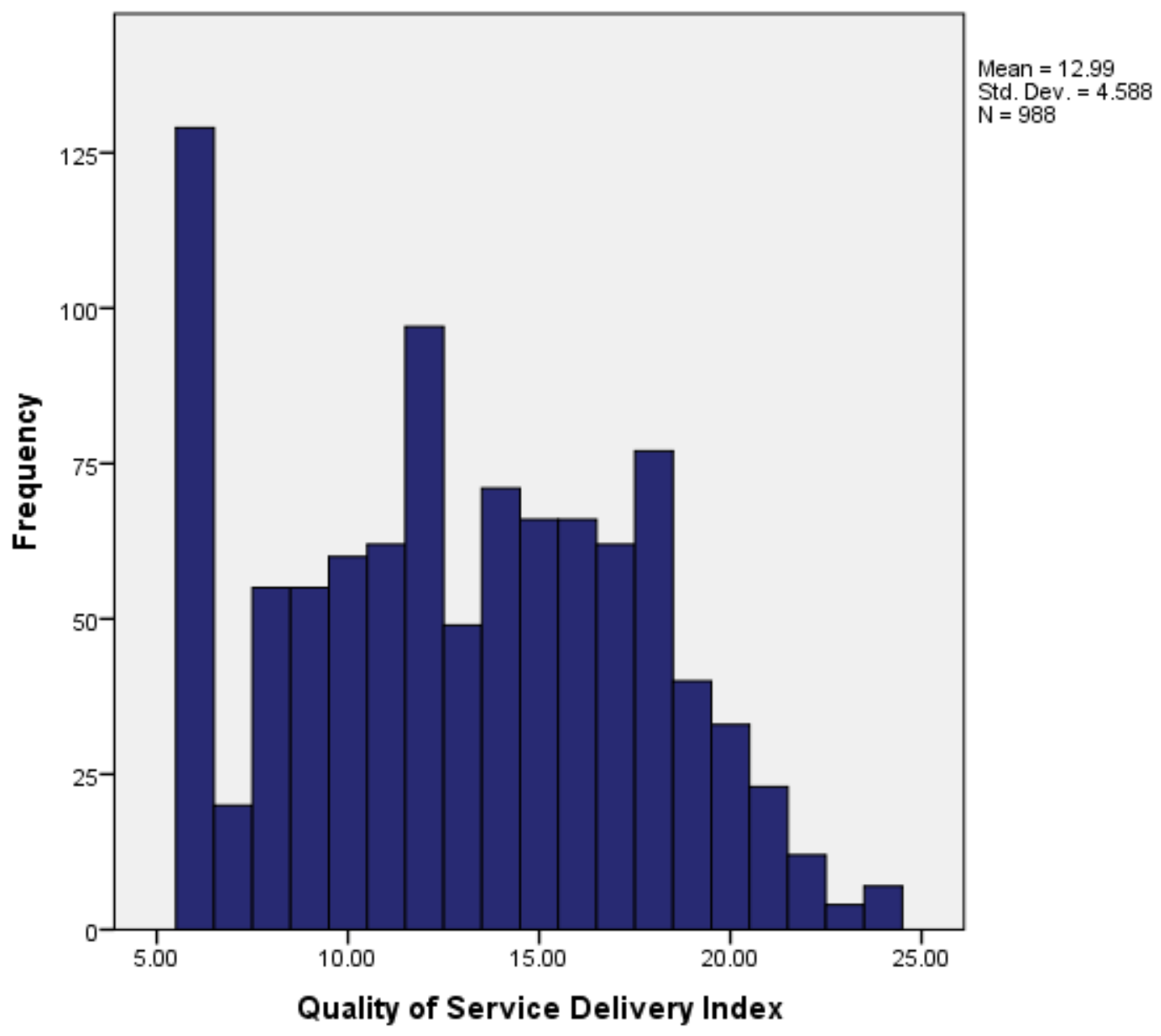




\begin{tabular}{|c|c|c|c|c|}
\hline \multicolumn{5}{|c|}{$\begin{array}{l}\text { Table 1. Model 1: Regression Coefficients for Local Political Participation } \\
\text { Coefficients }^{\text {a }}\end{array}$} \\
\hline \multirow[t]{2}{*}{ Model } & \multirow{2}{*}{$\begin{array}{c}\begin{array}{c}\text { Unstandardized } \\
\text { Coefficient }\end{array} \\
\text { B }\end{array}$} & \multirow[t]{2}{*}{$\begin{array}{c}\text { Significance } \\
\text { (Standard Error) }\end{array}$} & \multicolumn{2}{|c|}{ Collinearity Statistics } \\
\hline & & & Tolerance & VIF \\
\hline (Constant) & 4.812 & $\begin{array}{c}.000 \\
(.866)\end{array}$ & & \\
\hline Urban/Rural & -.519 & $\begin{array}{l}.081^{*} \\
(.297)\end{array}$ & .721 & 1.386 \\
\hline Gender & -.660 & $\begin{array}{l}.016^{* *} \\
(.273)\end{array}$ & .856 & 1.168 \\
\hline Age & .017 & $\begin{array}{c}.114 \\
(.010)\end{array}$ & .924 & 1.082 \\
\hline Education & .103 & $\begin{array}{c}.114 \\
(.065)\end{array}$ & .722 & 1.385 \\
\hline $\begin{array}{l}\text { Voluntary Group } \\
\text { Membership }\end{array}$ & .589 & $\begin{array}{l}.000 * * * \\
(.117)\end{array}$ & .903 & 1.107 \\
\hline Political Efficacy & .280 & $\begin{array}{l}.015^{* *} \\
(.115)\end{array}$ & .933 & 1.072 \\
\hline Local Political Efficacy & .320 & $\begin{array}{c}.009 * * * \\
(.121)\end{array}$ & .892 & 1.121 \\
\hline Party Attachment & .547 & $\begin{array}{l}.032^{* *} \\
(.254)\end{array}$ & .965 & 1.037 \\
\hline $\begin{array}{l}\text { Experience with } \\
\text { Corruption Index }\end{array}$ & .275 & $\begin{array}{c}.000 * * * \\
(.072)\end{array}$ & .856 & 1.169 \\
\hline $\begin{array}{l}\text { Local Accountability } \\
\text { Index }\end{array}$ & -.101 & $\begin{array}{c}.000 * * * \\
(.026)\end{array}$ & .871 & 1.149 \\
\hline $\begin{array}{l}\text { County-Level } \\
\text { Transparency }\end{array}$ & -.227 & $\begin{array}{c}.002 * * * \\
(.072)\end{array}$ & .856 & 1.168 \\
\hline
\end{tabular}

a. Dependent Variable: Local Participation Index

$\mathrm{N}=489$

R Square $=.253$

Adj. R Square $=.236$

$\mathrm{SE}=2.75990$

${ }^{* * *} \mathrm{p}<.01,{ }^{* *} \mathrm{p}<.05,{ }^{*} \mathrm{p}<.10$ 


\begin{tabular}{|c|c|c|c|c|}
\hline \multicolumn{5}{|c|}{ Table 2. Model 2: Regression Coefficients for Perceptions of Corruption } \\
\hline \multirow[t]{2}{*}{ Model } & \multirow{2}{*}{$\begin{array}{c}\begin{array}{c}\text { Unstandardized } \\
\text { Coefficient }\end{array} \\
\text { B } \\
\end{array}$} & \multirow[t]{2}{*}{$\begin{array}{c}\text { Significance } \\
\text { (Standard Error) }\end{array}$} & \multicolumn{2}{|c|}{ Collinearity Statistics } \\
\hline & & & Tolerance & VIF \\
\hline (Constant) & 11.943 & $\begin{array}{c}.000 \\
(1.356)\end{array}$ & & \\
\hline Urban/Rural & .657 & $\begin{array}{l}.069 * \\
(.361) \\
\end{array}$ & .746 & 1.341 \\
\hline Gender & .234 & $\begin{array}{c}.483 \\
(.333)\end{array}$ & .874 & 1.144 \\
\hline Age & -.001 & $\begin{array}{r}.915 \\
(.013)\end{array}$ & .885 & 1.130 \\
\hline Education & -.017 & $\begin{array}{c}.833 \\
(.081)\end{array}$ & .762 & 1.313 \\
\hline $\begin{array}{l}\text { Political Efficacy ("not at all } \\
\text { likely") }\end{array}$ & -.526 & $\begin{array}{c}.230 \\
(.438)\end{array}$ & .553 & 1.808 \\
\hline Political Efficacy ("not very likely") & .625 & $\begin{array}{c}.182 \\
(.468)\end{array}$ & .611 & 1.636 \\
\hline $\begin{array}{l}\text { Political Efficacy } \\
\text { ("very likely") }\end{array}$ & -.392 & $\begin{array}{c}.428 \\
(.494) \\
\end{array}$ & 638 & 1.568 \\
\hline Local Political Efficacy("nothing") & -.067 & $\begin{array}{r}.892 \\
(.495) \\
\end{array}$ & 648 & 1.543 \\
\hline $\begin{array}{l}\text { Local Political Efficacy ("small } \\
\text { amount") }\end{array}$ & .655 & $\begin{array}{c}.146 \\
(.450)\end{array}$ & .626 & 1.598 \\
\hline $\begin{array}{l}\text { Local Political Efficacy } \\
\text { ("a great deal") }\end{array}$ & .801 & $\begin{array}{l}.063 * \\
(.430) \\
\end{array}$ & .613 & 1.632 \\
\hline Party Attachment & -.516 & $\begin{array}{c}.114 \\
(.326)\end{array}$ & .908 & 1.101 \\
\hline Local Accountability Index & .043 & $\begin{array}{c}.287 \\
(.040)\end{array}$ & .623 & 1.606 \\
\hline County-Level Transparency & .290 & $\begin{array}{c}.005^{* * *} \\
(.103)\end{array}$ & .832 & 1.202 \\
\hline Quality of Services Index & -.160 & $\begin{array}{c}.000 * * * \\
(.043)\end{array}$ & .627 & 1.594 \\
\hline $\begin{array}{l}\text { Election Cleanliness ("not } \\
\text { free/fair") }\end{array}$ & .768 & $\begin{array}{c}.113 \\
(.484)\end{array}$ & .795 & 1.257 \\
\hline $\begin{array}{l}\text { Election Cleanliness ("free/fair with } \\
\text { major problems") }\end{array}$ & 1.676 & $\begin{array}{c}.001^{* * *} \\
(.503)\end{array}$ & .803 & 1.245 \\
\hline $\begin{array}{l}\text { Election Cleanliness ("completely } \\
\text { free/fair") }\end{array}$ & -.654 & $.088^{*}$ & .716 & 1.397 \\
\hline
\end{tabular}




\begin{tabular}{|l|c|c|c|c|}
\hline & & $(.383)$ & & \\
\hline $\begin{array}{l}\text { Satisfaction with Democracy } \\
\text { ("not at all satisfied") }\end{array}$ & 1.289 & $\begin{array}{l}.010^{* *} \\
(.497)\end{array}$ & .683 & 1.465 \\
\hline $\begin{array}{l}\text { Satisfaction with Democracy } \\
\text { ("not very satisfied") }\end{array}$ & .478 & $\begin{array}{c}.254 \\
(.419)\end{array}$ & .660 & 1.515 \\
\hline $\begin{array}{l}\text { Satisfaction with Democracy ("very } \\
\text { satisfied") }\end{array}$ & -.839 & $\begin{array}{c}.057^{*} \\
(.441)\end{array}$ & .657 & 1.523 \\
\hline
\end{tabular}

a. Dependent Variable: Perceptions of Corruption Index

$\mathrm{N}=853$

R Square $=.141$

Adj. R Square $=.120$

$\mathrm{SE}=4.54333$

${ }^{* * *} \mathrm{p}<.01, * * \mathrm{p}<.05,{ }^{*} \mathrm{p}<.10$ 
Table 3. Bivariate Analysis of Quality of Service Delivery

\begin{tabular}{|c|c|c|c|c|c|}
\hline \multirow[t]{2}{*}{ Model } & \multicolumn{2}{|c|}{ Unstandardized Coefficients } & \multirow{2}{*}{$\begin{array}{l}\text { Standardized } \\
\text { Coefficients } \\
\text { Beta } \\
\end{array}$} & \multirow[t]{2}{*}{$\mathrm{t}$} & \multirow[t]{2}{*}{ Sig. } \\
\hline & B & Std. Error & & & \\
\hline (Constant) & 5.211 & .190 & & 27.486 & .000 \\
\hline Local Accountability Index & -.182 & .010 & -.495 & -17.632 & $.000^{* * *}$ \\
\hline
\end{tabular}

a. Dependent Variable: Service Delivery Index

$\mathrm{N}=961$

R Square $=.328$

Adj. R Square=.327

$\mathrm{SE}=4.01067$

$* * * \mathrm{p}<.001$ 